\title{
Kogukonna kodulehekülg geopeitus.ee kui traditsiooni varamu
}

\author{
Mare Kalda
}

Teesid: Internetilehekülg www.geopeitus.ee kajastab erilise, infotehnoloogia abil mängitava aardeotsimismängu kulgu. Lisaks otseselt mängu puutuva dokumenteerimisele teevad geopeitjad etnograafilisi tähelepanekuid ning pildistavad ja kirjeldavad pärimusega seotud kohti ja objekte. Samuti jäädvustavad nad ühiselt käigus hoitaval mängu koduleheküljel tähelepanekuid ümbritseva maailma kohta. Teatud mõttes toimivad nad ühekorraga nagu pärimusrühm, kes harrastab erilist praktikat, ja nagu etnoloogid või folkloristid, kes loovad selle tegevuse kirjeldust autoetnograafilist meetodit rakendades. Kõige selle tulemusel moodustab geopeituse lehekülg huvitava andmekogu, mis ahvatleb erialateadlasi toimuvat jälgima, paeludes näiteks kommunikatsiooniuurijaid, kultuurigeograafe, psühholooge, mänguanalüütikuid, IT valdkonna arendajaid, aga ka etnolooge ja folkloriste. Folkloristi jaoks on huvitavaks väljakutseks küsimus ainestiku kogumisest. S.t kui traditsiooni talletavad asjaga seotud kogukonnad ise ühises info-ja suhtluskeskkonnas, kui nad pidevalt ja mitmekülgselt peegeldavad oma tegemisi online, siis kuidas tuua sel viisil saadud sisukas andmekogu folkloristlike allikate hulka?

Märksõnad: folkloori kogumine, geopeitus, internet kui arhiiv, koostöö pärimusrühmaga 
Iga kord, kui ühiskondlikes protsessides avalduvad kas näivalt või ka tegelikult uued ilmingud, saadab neid ja reageerib neile folkloor. Sellest tekivad küsimused, missuguseid rahvaliku loovuse saadusi ja rohujuuretasandi reageeringuid peaks jäädvustama, et uute ajastute saabudes oleks mineviku traditsioonide kohta piisavalt allikaid. Või et uuel ajastul oleks nende abil võimalik representatiivselt kõnelda möödaniku praktikatest. Kirjakultuuri tingimustes ei tundu see olevat märkimisväärne probleem, sest allika väärtuses dokumente, raamatuid, kirju, päevikuid, märkmelehti, fotosid, videoid ja helisalvestusi leidub nii institutsioonide arhiivides kui ka kappides ja kaustades inimeste kodudes, rääkimata digifailidest arvutites. Isegi kui peaks millegipärast otsustatama, et teateid mineviku kohta ei vajata, võidakse tunda tarvidust jäädvustada toimuvat sünkroonselt kui mitte tuleviku, siis näiteks protsessidesse kaasa haaratud osalejate endi huvidele vastamiseks olevikus.

Käesolevas artiklis arutletakse geopeituse - infotehnoloogia abil mängitava aareteotsimise mängu tähenduslikkuse üle folkloristliku uurimisobjektina. Suures osas on geopeituse uurimine Internetti üles laaditud materjali uurimine, kuna mängu käik on harrastuse kodulehekülje (kodulehekülgede) abil suurepäraselt jälgitav. Tegelikult on geopeituse puhul huvipakkuv sisu juba ära kogutud ja enamgi veel: osalejad on kandnud andmed korralikult struktureeritud andmebaasi. Potentsiaalne uurija kogeb olukorda, kus traditsioon või tegevusžanri näide on koondatud mitte rahvaluulekogumise eesmärgil, vaid kaasategijate endi poolt. Kas sel juhul on vajalik spetsiaalne kogumistöö folkloristlike allikate saamiseks? Selliselt formuleeritud küsimus võiks kutsuda dialoogile teisi kultuuriuurijaid, kes samuti on ära tundnud Internetis leiduvate andmekogude, lugude, kõneluste, mõtteavalduste ja muu loomingu allikaväärtuse. Kuigi nimetatud seik kitsendab teatud määral töö potentsiaalset lugejaskonda - küsimus, kas ja kuidas internetivoogudest leida pärimuse uurimiseks vajalikku ainet, huvitab digitaalselt leviva traditsiooni jälgijaid - pean seda siiski põhjendatuks. Pole ju geopeitus kaugeltki ainuke tegevus, mis justkui ise ennast digitaalselt representeerib. Tänapäevase nähtuse salvestamisel - nii näidete allalaadimisel kui muul moel väljavõtete tegemisel, rääkimata lauskopeerimisest, peab olema tagatud intellektuaalomandi kaitse. Eesti geopeituse kodulehekülge haldab ja koordineerib Geopeitus MTÜ, kes mängureeglite tutvustuses oma 
autoriõigust ei deklareeri. ${ }^{1}$ See-eest tuleb esile platvormi kasutajate vastutus aardekirjelduste, logide, piltide, foorumisissekannete jne sobilikkuse osas, rõhutatakse, et need peavad vastama geopeituse headele tavadele ja muidugi seadustele ning sedastatakse, et "iga geopeitus.ee kasutaja vastutab isiklikult oma geopeitusega seotud tegevuse või tegevusetuse ja sellest tulenevate tagajärgede eest" (vt Mängureeglid [2018]). Geopeituse eripäraks on andmete ühine lisamine ja töötlemine ning mängu ühine käimashoidmine individuaalsete soorituste kaudu. Kui ka harrastuse andmekogu on tõlgendatav kui teos, millele rakendub autoriõiguse seadus, siis toimivad paljud autoriõiguse seaduse peatükk 2 paragrahvides 18-20 loetletud tingimused (teose kasutamisest autori nõusolekuta ja tasu maksmiseta; vt AutÕS). § 19 punktid 1-3 seadustavad teose vaba kasutamise teaduslikel, hariduslikel, informatsioonilistel ja õigusemõistmise eesmärkidel (tsiteerimine ja refereerimine motiveeritud mahus, kasutamine illustreeriva materjalina ärilise eesmärgita); $\S 20$, mis käsitleb teose vaba kasutamist avaliku arhiivi, muuseumi või raamatukogu poolt, sisaldab koguni võimalust digiteerida kogu säilitamise eesmärgil (samas, $§ 20$ punkt 2).

Artiklis vaagitakse ühtlasi rahvuskultuuriliselt oluliste võrguressursside valikukriteeriume, mis geopeituse inforikkusega kõrvutades viivad ideeni, et ka mängu käigus moodustatud unikaalne andmekogu vääriks varundamist.

Mängude uurimises üldisemalt ollakse seisukohal, et parim viis toimuva mõistmiseks ja mõtestamiseks on kaasategeva uurija positsioon (Aarseth 2003; Montola 2012, 313 jj). Olen nimetatud kriteeriumi tõsiselt võtnud ja mängin geopeitust alates selle Eestis toimumise algusaastast. Mängijana olen vaoshoitud, eesmärgiks pole kunagi olnud skoorimine ${ }^{2}$ ega erilist otsimisvarustust ja -oskusi

${ }^{1}$ Portaalis sisalduvate andmete autoriõigus on selgelt esile toodud paljudes keskkondades kasutustingimuste tutvustustes. Näiteks tuntud platvorm Perekool.ee määratleb seal leiduvate materjalide (artiklid, lehe kujundused, pildi- ning videomaterjal jms) omanikuna Eesti Ämmaemandate Ühingu ning defineerib, missugustel tingimustel tohib informatsiooni reprodutseerida (vt https://www.perekool.ee/artiklid/toimetus/kasutajatingimused/).

${ }^{2}$ Skoorimine on geopeituse sõnastikus (vt https://www.geopeitus.ee/wiki/ sonastik) määratletud järgmiselt: Skoorimine - suure hulga aarete leidmine suhteliselt lühikese aja jooksul. [---] Aare püütakse kiiresti leida, logida ja kohe edasi liikuda ilma aarete juures ümbrust, loodust, matkaradu, vaatetorne jm vaatamisväärsusi külastamata [---]. 
nõudvate aarete leidmine. Huvitavat lisa pakuvad harrastuse uurijale geopeitust tutvustavad uudislood meedias, mis tegelevad kas geopeituse "avastamisega" (tavaliselt kajastavad ajakirjanduslikku eksperimenti ja sisaldavad põgusat jutuajamist mõne autoriteetse geopeitjaga; vt näiteid allpool) või siis lähtuvad mingist konkreetsest geopeituse ja ümbritseva maailma kokkupõrkest. Niisugustel meediatekstidel tasub silm peal hoida, kuna seal väljendub mitmesuguseid mittemängiva üldsuse arvamusi ja hinnanguid (kommentaarium kaasa arvatud). Enne otseselt geopeitust puudutavate küsimusteni jõudmist on toodud põgus ülevaade folkloori kogumise kauakestvatest eesmärkidest ja põhimõtetest, kuna need kehtivad suures osas ka nii uuel ajal ja uudse nähtuse kohta kui seda on 21. sajand ja infotehnoloogia rakendamine peitusmängu huvides.

\section{Väärilise mineviku loomise otstarbest uue kultuurikirjelduseni}

19. sajandi rahvaluulekogumine tähendas minevikupärimuse, "rahva mälestuste ehk vanavara" kokkukandmist "Eesti muinasteaduse ülesehitamiseks" (Hurt 1963 [1871, 1888]). Madis Arukask rõhutab niisuguse kogumise puhul ärkamisaja konteksti, mil oli vaja folkloori koguda väärilise mineviku loomiseks ja lähtekoha kindlustamiseks tulevikku siirdumisel $(2017,16)$. Toonane kogumistöö initsiaator Jakob Hurt oli juba 1871. aasta kogumisjuhises väga metoodiline: et ära tunda, mida rahva mälestustest pidada, tuli seletada, mis rahva mälestused on. ${ }^{3}$ Jakob Hurda sõnul on mälestused väär-

${ }^{3}$ Jakob Hurt kirjutas 1871. aasta üleskutses: "Rahva mälestuste hulka tulevad arvata: Esiteks jutustused mitmesugustest sündimustest ja juhtumistest esivanemate ajal, nagu sõdadest, katkudest, mõne mehe vägevaist, ausaist ehk muido tähelepanemise väärt tegodest ja muist niisugusist asjost; tõiseks kõik mälestused vana rahva kodosest elost, nende pruukidest, kombetest, pidodest, töötegemise viisist ja korrast, nende seadustest ja valitsusest; kolmandaks kõik tunnistused vana aja usust ja vaimu elost, olgu usk ehk vaimu elo missugune tahes olnud, paganaline või kristlik; neljandaks kõik märgoanded esivanemate vaimuharimise järjest ja nende mõistuse ja meele teravusest, nimelt kõik ennemuistsed jutud, rahva laulud ehk regevärsid, mõistatused, vanad sõnad, tähtsad kõnekäänud ja mõnesugused arvamised, kas loodud asjadest või muust, mis inimese südant liigutab ja teda mõtlema paneb; viiendaks mõned iseäralised pruugid ja viisid, mis vanast ajast järele jäänud ja nüüd veel rahva elos ja olos mõnes paigas näha, iseäranis mitmesugused ebausu kombed ja kõrvalised toimetused töö ja ammeti tallituste juures" (1963 [1871], 192-193). 
tuslikud - sest need õpetavad vana aega tundma kui suur ja elav ajaraamat; nad on kaunid kuulda kui "lõbus ajaviide ja mõnos meelelahotus"; vanad laulud ja jutud sobivad lastekasvatuses ja koolis tähelepanu- ja mõtteharjutuseks; mitmes seisuses ja ametis on rahva mälestuste tundmist vaja (isegi "inetute ja kahjoliste mälestuste" tundmist; vt Hurt 1963 [1871], 192, 194, 197-199). Mari Sarv ja Taive Särg loetlevad samu aspekte seoses küsimusega rahvaluulekogude adressaadist 21 . sajandi kontekstis. "Kelle jaoks on mõeldud eesti rahvaluulekogud?" küsivad nad Eesti mäluasutuste suveseminaril Viinistus 2016 ning sõnastavad rahvaluulekogude kasutusvaldkonnad, milleks on:

- teadmiste kogu loomine eestlaste omakultuuri, mineviku kohta

- folkloorile tugineva rahvusliku kõrgkultuuri loomine

- esinemis- ja harrastustegevused (folkloori põhjal)

- ärilised ja äri toetavad tegevused ja tooted

- rahvaluule uuskasutus informaalses sfääris (Sarv \& Särg 2016; ka Sarv 2017).

Sellest lähtuvalt on rahvaluulet jäädvustava(te) ja uuriva(te) institutsiooni(de) ülesandeks kogude säilitamine, korrashoid ja täiendamine, mitmesugustele kasutajatele kättesaadavaks tegemine, samuti kogutu teaduslik mõtestamine ning uurimistulemuste vahendamine. Minevikulise, hääbuva traditsiooni talletamise asemel jälgitakse pigem kaasaegseid kultuuriprotsesse ja neis väljenduva rahvaliku loovuse saadusi. Kuigi professionaalsete folkloristide poolt rakendatud rahvaluulekogumise metoodika frontaalse kogumise printsiip (Saarlo 2017, 32-33) on andnud rahvaluulearhiivi sisukat materjali, on muidugi õige Madis Arukase tõdemus, et kogumisel tuleb teadvustada, mida ja milleks jäädvustada. Kogu kultuurilist käitumist pidevalt ja tervikuna pole võimalik talletada, isegi mitte väikesearvulise rühma oma (Arukask 2017, 13).

Ent kas on infotehnoloogia ajastu toonud olulisi muutusi ka folkloori kogumise võimalustesse ja viisidesse, kas ehk on osalusveeb ja inimeste aktiivsus virtuaalses suhtlemises ja infotarbimises veelgi kasvatanud rahvaluule salvestamist muul kui kultuurikirjelduslikul eesmärgil? Näiteks Ergo-Hart Västrik räägib rahvaluule jäädvustamisest lisaks akadeemilisele uurimistööle seoses piirkondliku või rahvusliku eneseteadvuse loomise vajadusega ja sooviga talletada oma kodukoha kultuuripärandit, samuti tahtest koondada niisugu- 
seid mitte-institutsionaalse kultuuri avaldumisvorme, mida muidu ei dokumenteeritaks (Västrik 2017, 29).

Käesoleva artikli fookuses on geopeitus kui spetsiifiline kultuuriline praktika ja harrastajate tegevusega loodav ning funktsioneeriv rühmatraditsioon eelkõige fenomeni jäädvustamise aspektist. Kas geopeitust saab koguda rahvaluule klassikaliste kogumismeetoditega? Kas aja proovile üldjoontes vastu pidanud kogumiseesmärgid on kohandatavad uutmoodi aardeotsimismängu jälgimiseks, kui uuritava tegevuse sooritamiseks ning osalejate omavaheliseks suhtluseks vajatakse ja kasutatakse digitaalseid informatsiooni- ja tehnoloogiavahendeid? Teotsemise iseloomu poolest on geopeitus üldisemalt tegevusžanr (nagu mäng, rahvadraama, rituaal, festival, kombetäitmine, vt Abrahams 1977; Kapchan 2003) - kehalise ja kogemuslikuga põimuvad vaimne pingutus ning kujutlusvõime. Niisuguste nähtuste talletamisel on oluline, et nimetatud dimensioonid oleksid kirjelduses kas nähtaval või vähemalt välja loetavad.

\section{Geopeitus kui traditsioon}

3. mail 2000 USAs Oregoni osariigis käima läinud geocaching (vt www.geocaching.com) ja selle kohalik, Eesti versioon geopeitus (alates veebruarist 2001; vt www.geopeitus.ee) nagu teisedki kohalikud "geopeitused" on igas mõttes tõlgendatavad mitteinstitutsionaalse kultuuri(pärandi) osa või ilminguna. Harrastus loob ühtlasi spetsiifilist kultuuri, kujundab traditsiooni. Mängu toimumise aastate jooksul on vormunud selle rahvusvaheline, isegi globaalne praktiseerimisviis, millega paralleelselt ilmuvad kohalikud erijooned väiksemate geopeitjakogukondade mängu käigus. Seniöeldu ei eelda, et geopeitus tuleks tingimata defineerida rahvaluuleks, kuid tunda on traditsiooni puudutust. Elliott Oring leiab, et vaadeldava nähtuse määratlemisega traditsiooniks markeerivad folkloristid nähtuse selliseks alaks, mis on väärt uurimist (Oring 2013, 42). Niivõrd kuivõrd geopeitus on mäng, paigutub ta traditsiooni juba žanriliselt - kuigi seniste peitusemängudega võrreldes piisavalt teistsugune, on rakendatud siiski mängulise asjadepeitmise-leidmise põhiideed või isegi arhetüüpi. Geopeitust harrastades hoiavad kaasategijad mängu käigus, iga sel eesmärgil sooritatud aktsiooniga loovad nad geopeituse traditsioone. 
Traditsiooni puudutus ilmneb geopeituses ka selles mõttes, et mängijad pöörduvad pärimuse poole, et saada inspiratsiooni uute aarete kujundamisel - folkloori digiväljaanded ja rahvaluule andmebaasid toimivad informatsiooniallikana. Mängus vajatakse muistendeid ja muinasjutte taustalugudeks, aarete otsimisraportites ehk logides kohtab naljandeid ja anekdoote (näiteks ühe Tallinna linna-aarde logidesse (vt Lacrimae professorum 2009) kogunes valik professorinalju ${ }^{4}$ ), mängus kaasatakse mõistatused, vanasõnad, populaarkultuuri tegelased - niisiis leiab kasutamist mitmekesine folkloorne materjal. Lisaks tekstide rakendamisele mängu huvides tähistab geopeitus rahvakalendri tähtpäevi. Kuna ka tähistamine nagu muudki geopeituses toimuvad sündmused ja teod on kajastatud geopeituse kodulehel, on mängijatel endal ja igal huvilisel, kaasa arvatud folkloristil, kasutada harrastusega seotud kalendrikombestiku kirjeldused. Osaliselt tehakse samu tegevusi, mis on kombeks antud kultuuris üldisemalt (näiteks vastlapäevane liulaskmine). Isegi kui ei koguneta füüsiliselt (näiteks kaks naistepäeva-aaret, vt Naistepäeva 2012 ja Naistepäeva 2, 2013), on tähtpäeva pidamine geopeitjate kogukonnas eriline harrastusega sidumise tõttu ja seda rõhutab ka nimetamisviis - vastlapäev ei ole tavaline, vaid geovastlapäev ${ }^{5}$. 24. juuni on geojaanipäev või geojaan ning seda on tähistatud alates 2007. aastast igal aastal. Hoolimata päeva nimetusest ei koguneta päris-jaanilaupäeval ega jaanipäeval, mis loovutatakse hariliku jaaniõhtu rituaalidele pere või mittegeopeitjatest sõprade seltsis. Ühiskogunemised kujutavad endast erilist liiki aaret: sündmusaaret, millest osavõtt kajastub geopeitjate leiustatistikas. Sageli sisaldab sündmusaare veel eripeidikuid, mille otsimisega kokkutulnud tegelevadki lisaks seltskonna nautimisele. Sündmusaare on harrastajaskonna kokkutulek geopeituse moodi - geopeitjate kohtumisrituaal, mille kestel osa tegevusi sarnanevad igasuguse kokkutuleku tegevustele, kokkutuleku ajend ning meelestatus aga on selgelt harrastusepõhine.

\footnotetext{
${ }^{4}$ Aarde peitja palus leidjatel lehel logides lisada anekdoot, milles tegelaseks õppejõud, ning pakkus omalt poolt ühe: Professor manitseb lärmakaid tudengeid: "Iga kord, kui ma suu lahti teen, hakkab keegi lollpea rääkima." Lacrimae professorum oli leitav septembrist 2009 kuni maikuuni 2016, mil aare arhiveeriti. See tähendab, et logid aarde külastuste kohta on endiselt mängijatele vaadatavad, ent aaret füüsiliselt enam peidikus ei ole. Aarde ajaloo 228 leidmis- ja 22 mitteleidmise logis on 79 anekdooti ja pajatust. ${ }^{5} \mathrm{Vt} \mathrm{http://www.geopeitus.ee/index.php?p=301 \& name=vastlap \% C3 \% A4.}$
} 


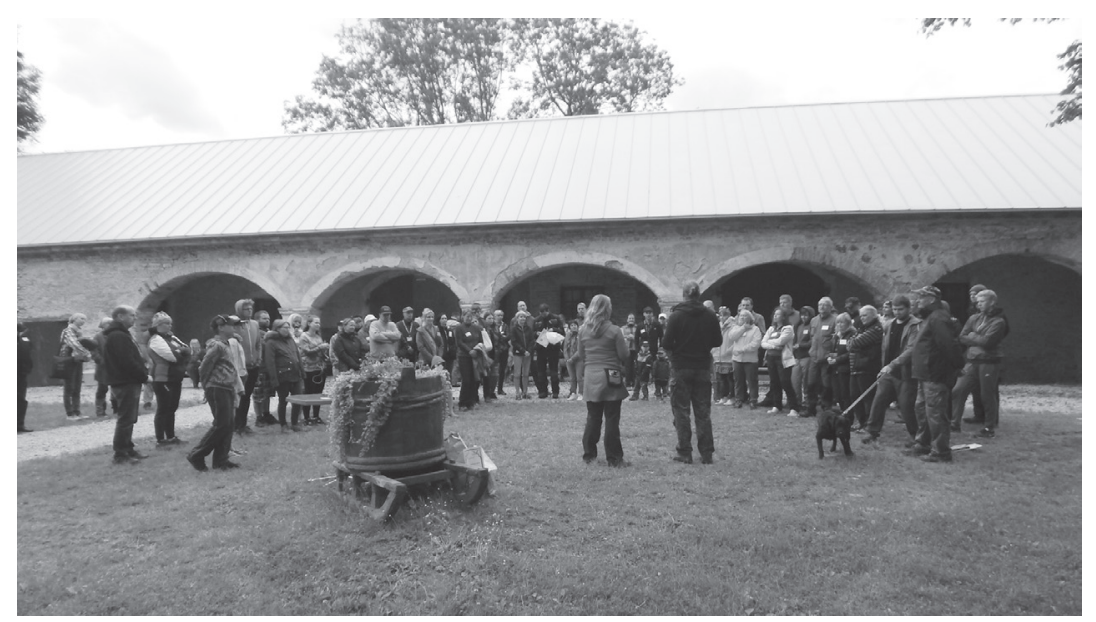

Geopeitjate kokkutulek ehk sündmusaare 30. juunil 2018 Pagari mõisas. Ühine jaanipäeva-aegne kokkusaamine on kujunenud geopeituse üheks rituaaliks. Foto: geopeitus.ee.

Geopeitust saab harrastada tegelikult kaasmängijatega kokku puutumata. Kogu mängualane suhtlus ja igaühe mängukordade ülevaade on kogukonnale kättesaadav, isegi teistega otseselt tutvumata tekib kiiresti tunne, nagu kuuluksid logides ning foorumikõnelustes märgatud kasutajad kas lausa tuttavate hulka või siis vähemalt muutuvad inimesteks, keda teatakse. Oletan, et nii mõnigi harrastaja jagab geopeitja Kolla ${ }^{6}$ mõtteid, nii nagu need on väljendatud foorumikõneluses 2011-2012, mil postitajad arutlesid oma geopeitjakogemuste ning muljete üle. Ta kirjutas muuhulgas:

\begin{abstract}
[---] Ma ei käi üldiselt kokkutulekutel ja sündmusaaretel, kuid sellegipoolest on kogu aktiivselt mängiv osa peituritest nagu vanad sõbrad. Eks osasid olen ka juhtunud siin-seal nägema, teisi tead piltidelt ja isegi kui ei tea, ikkagi on täiesti tunne, et oled "omade" seas. Ka siis, kui oled kirjutanud ja igasugu geoasju arutanud, on niisugune küünarnukitunne olemas. Seda enam, et rahvas on väga sõbralik ja abivalmis [---] (postitus 15.02.2011 foorumis "10 aastat geopeitust Eestis")
\end{abstract}

${ }^{6}$ Geopeitjatele viidates olen kasutanud nende kasutajanimesid. Kuna tegu pole isikunimedega, on need esitatud kaldkirjas. 
Geopeituse aastad näitavad, et ei mingit "üksildast bowlingut" (vrd Putnam 2000) - jah, internetikogukond küll, aga soovi ja võimaluse korral kogunetakse ka tavamaailmas. Kaasategijad on selgelt eristuv rühm, kes ühise harrastuse käigus jagavad informatsiooni ja suhtlevad mängualaselt online (enamasti asünkroonselt), kuid samahästi tekivad vahetud kokkupuuted, saadakse tuttavaks ja isegi sõpradeks. Keskkonda YouTube.com on üles laaditud sadu videoid suurematest geopeituse sündmusaaretest ehk geopeitjate kokkutulekutest mitmel pool maailmas. Lisaks muule folkloorile, mida geopeituses kasutatakse või mis ilmestab logisissekandeid, luuakse mängualast informatsiooni edastades ning foorumites ja silmast silma suheldes erilist geopeituse-folkloori: geopeituse nalju, sõnavara, lugusid, uskumusi, endeid, isikukogemuse jutte, vanasõnu, mõeldakse välja mõistatusi. Kultuuris traditsioonilised žanrid leiavad rakendust, harjumuspärane vorm täidetakse uue, harrastuspõhise sisuga. Geopeituse kui mängužanri järjekordse ilmingu üheks täiesti uueks omaduseks on tegevuste regulaarne kajastus. Uus aare läheb uuele aardeleheküljele üles, sinna ilmuvad ajalises järjekorras otsijate logiteated otsimise protsessi ja tulemuste kohta. Geocaching.com ei soosi logides lugudejutustamist (tuhandete sissekannete puhul oleks seda ka palju nõuda), selleks on sisustatud eraldi foorumid, kuna inimesed tõepoolest tahavad oma geootsingutest pikemalt jutustada. Eesti mängus, kus aarete külastuskordade arv on ka juba küllaltki suur, on individuaalsest missioonist teatamine vabam. Sõnumitesse mahub mahlakaid väljendeid, miniformaadis leiulugusid, intertekstuaalseid vihjeid mitmesugustele kultuuriseostele, muljete ja elamuste kajastusi, aga ka märgatud olukordade lühikirjeldusi - nende hulgas folkloorseid ning peaaegu-folkloorseid väljendusi. Kuid see kõik on ju väärt traditsiooni raames kogumist ja läbivaatamist.

Mitmed geopeituse uurijad on andmekogumisel läinud traditsioonilist rada, on tehtud intervjuusid võtmemängijatega, on palutud täita veebiküsimustikke (O'Hara 2008; Neustaedter \& Tang \& Judge 2010; Ihamäki 2015). Tegelikult saab vastuseid neile küsimustele, mida küsimustikes esitatakse, foorumipostitustes niikunii - näiteks kuidas keegi liitus geopeitusega, mis harrastuse juures köidab, missuguseid aardeid eelistatakse otsida, missugused on kokkupuuted teiste mängijatega jne. Pean oluliseks kaasategeva uurija positsiooni - see ei ole otseselt ainestiku kogumise probleem, aga nüanss, mis kahandab distantsi uurija ja uuritava praktika vahel; kogemuslik 
ühisosa teiste mängijatega, tavalise geopeitja rollis tegutsemine laseb kaasharrastajate poolt kirjapandut paremini mõista.

Nagu öeldud, on mängu sooritused geopeituse (ja geocachingu) koduleheküljel (lehekülgedel) osalejate endi poolt põhiliselt kajastatud ning foorumiaruteludes pühendatakse palju energiat rühmaidentiteedile, tegevuse enesereflektsioonile. Kui nüüd geopeitus satub kultuuriuurimise fookusesse, siis on põhjust küsida: kas isekogunevad andmed uuritava protsessi kohta (selles mõttes isekogunevad, et vaatleja ei tee jõupingutusi nende esilekutsumiseks) on kasutatavad kui juba koondatud uurimisallikas? Individuaalse uurimiskogemuse põhjal vastaksin sellele jaatavalt. Aardelehekülgede, otsimislogide ega foorumipostituste eesmärk pole luua etnograafilist kirjeldust. Sellist eesmärki taotlemata on minu hinnangul see ikkagi saavutatud - mänguetapid, mängus ette tulevad olukorrad on üles kirjutatud ja salvestatud ning andmebaasis korrastatult esitatud. Geopeituse portaal - primaarselt harrastajaskonna online andmehoidla ja meedia - kujutab endast ühtlasi isekoonduvat andmekogu, otsekui realiseerides võrdlev-ajaloolise koolkonna folkloristi unistust vaatlusaluse nähtuse kõikide variantide kättesaamisest. ${ }^{7}$ Niisugusel juhul võib tunduda, et isegi ainestiku väljavõtete allalaadimine pole kuigi oluline, sest saidil olev sisu on virtuaalis kogu aeg alles (vrd Maili Pildi kogemusega: "Kogu materjali täiendav salvestamine ja talletamine failidena võib vähemasti välitööde algusjärgus tunduda tarbetu" (2017, 174-175)). Isegi aktiivsest mängust kõrvale jäänud aarete informatsioon on vaadatav, kuigi selliseid aardeid reaalselt leida enam võimalik ei ole. Sellegi poolest olen pidanud vajalikuks aeg-ajalt salvestada näiteid ning fotosid ja teha koopiaid ühe või teise aarde logidest - saadud "tagavarakoopiadki" kuuluvad minu uurimisallikate hulka.

Geopeituse saitidel olevate andmete hooldamine näitab internetikogukonna tegelemist oma traditsiooniga, selle kogumist ja korrastamist (on kasutusel funktsionaalne andmebaas, päringuvõimalused, statistika, kaardi- jm rakendused, hoitakse mängu korda ja lahendatakse probleeme). Merrill Kaplan on teinud tähelepanekuid folkloorihuvi alusel kujunevate virtuaalsete rühmade tegevuse kohta: vähem kui ainestiku esitamine on see materjali kogumine,

${ }^{7}$ Isekoguneva, täpsemalt justkui iseenesest arhiveeruva folkloori ideest (FB as a dynamic self-archiving folklore collection) on kirjutanud Facebooki näitel ning seoses suurte pärimusandmekogude võimalike uurimismeetoditega Timothy Tangherlini $(2013,15)$. 
indekseerimine ning kirjeldamine nende endi poolt (Kaplan 2013, 129). Mitte ainult folkloristid ei uuri rahvaluulet, vaid rahvas ise ka uurib, "folkloori analüüs on saanud vernakulaarseks praktikaks", kirjutab ta (samas, 126-127). Kaplan võrdleb kasutajate poolt hallatavat ja uuendatavat folkloorisaiti artefaktidega tegeleva muuseumiga: kogusid korrastatakse, indekseeritakse, kommenteeritakse ja pannakse välja teistele kasutamiseks. Geopeituse puhul on andmete üleslaadimise ja saadavaloleku peaeesmärgiks juurdepääs informatsioonile, andmekasutus mängu online-keskkonnas kujutab endast ühte aktiivse mängu etappi. Igaks otsinguks tuleb valida internetilehelt aarded, tahtmise korral või vihjete lugemiseks saab tutvuda teiste otsijate kogemustega, otsingu tulemustest on vaja koostada logi, mis liitub aarde senise informatsiooniga. Muidugi arhiivi või muuseumi kombel "säilikute" eest hoolitsemise analoogia toimib teatud määral ka geopeituses. Aarde omanik lisab oma aardele täiendavat informatsiooni; kui vaja, kontrollib reaalset peidikut. Administraatorid mõtlevad välja (sageli kasutajate ettepanekute põhjal) uusi kasutajaliideseid, otsinguvõimalusi jm uuendusi, korrastavad reegleid. Mängus olevate aarete, nagu ka geopeituse muude tahkude üle, arutletakse foorumites.

Geopeituse seisukohalt tunduks idee harrastuse kajastust kuidagi eraldi koguda või mujale dubleerida pigem ülearune. Näiteks üks resultatiivsetest mängijatest kutsus jaanuaris 2011 (seoses eesti geopeituse 10 aasta täitumisega) teisi osalejaid foorumis mõtteid vahetama, kuidas keegi alustas ja mis harrastuse juures köidab. On ilmne, et tema küsimusi esitaks iga geopeituse etnograaf oma uurimistöö intervjuuvoorus. Geopeitja Pekadrip, üks aktiivsematest mängijatest, postitas toona järgmise üleskutse:

Mõeldes tulevastele põlvedele, kes aastate pärast tunnevad põletavat
uudishimu teada saada, kuidas eelajaloolised saurused ehk siis
meie (-) mängisime geopeituse mängu 21. sajandi alguses, avan siin
võimaluse mokalaadaks. Muljetage teemadel, kuidas avastasin enda
jaoks geopeituse, miks sellega ikka veel tegelen, mis kõige rohkem
meeldib, minu kõige-kõige eredam mälestus seoses geopeitusega ja
muu, mis haakub eelnevaga. Kuna tänapäeval keegi enam paberit
ja pliiatsit kasutada ei viitsi, on selline mokalaat peaaegu ainus
võimalus midagi talletada $:-)$

Niisiis kaasategijate jutustatud lood - postitused vastavas foorumis nagu ka kogu mängu kajastus (kõigi aarete leheküljed koos logidega) võiksid rahuldada tulevaste põlvede uudishimu, kui muidugi 


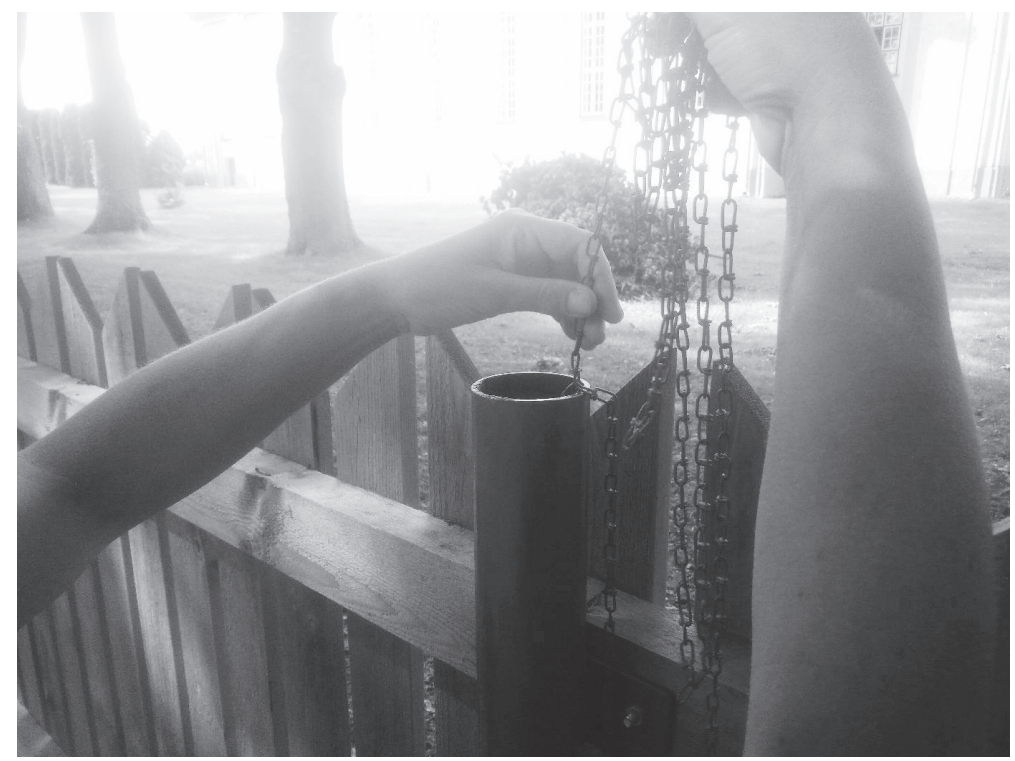

Geopeitjad kogevad aardeid otsides riukalikke peitmisviise. Miniatuurne aardetuub pika keti otsas ühes Lõuna-Eesti väikelinnas. Priit Kalda foto 2018.

geopeitus.ee on endiselt töös ja leitav. Seni kuni Eesti geopeitjate kogukond hoiab käigus ühist harrastust ning hooldab harrastuse internetikajastust kodulehel, ei tundu mängu representatsiooni (dokumentatsiooni) olemasolu ohus olevat.

\section{Pildi sisse minek: geopeituse pildipank}

Üheks eristatavaks informatsiooni formaadiks mängus ning allikaliigiks harrastuse vaatlejale mängust väljaspool on logidesse üles laetud fotod aarete lehekülgedel. Teatud mõttes sarnanevad aarete alamleheküljed online-meedia saitidele, kus uudise sõnalist osa illustreerivad visuaalsed kujutised, enamasti fotod (videod logisissekannetes on haruldased), kuid on ka joonistusi, tabelülesandeid, arvmõistatusi), toodud on linke ja viiteid teistesse võrgukohtadesse, 
tsiteeritakse mujal leiduvaid tekste. Seega on harrastuse kodulehekülg multimeedia keskkond. Kuid fotod ei ole siin üksnes reportaaži tugi, need osalevad kogukonna suhtluses ja neid vajatakse uute otsimiskordade planeerimisel. Pildi "lugemine", pildi sisse minek, võimaldab foto vaatajal ja logi lugejal osa saada kaasmängijate kogemustest, neid enda omadega võrrelda. Muidugi ei ole kuhugi kadunud foto omadus luua tegelikkuse efekti. Otsimiskohal tehtud võte dokumenteerib külastuse, ent samal ajal peegeldab nii geopeitust kui ka geopeituse-väliseid asjaolusid (nagu muidugi ka verbaalne kirjeldus). Tõsi küll, pidevalt täieneb andmevoog, mis asetab igasugused asjaolud, olendid ning sündmused geopeituse raamidesse. Kõigest kokku moodustub huvitav kaasharrastajatega jagatud muljete ja informatsiooni põimik. Internetisait osutub omalaadseks pildipangaks, mis kajastab harrastust, kuid ka loodust ja sotsiaalkultuurilist situatsiooni, siin on esindatud nii sündmuslikud kui keskkondlikud fotod (Puik 2008, 6). Geopeitjad pildistavad ootuspäraselt geopeituse eri tahke: otsimisprotsessi, harvem peitmishetki, aardeid (suletud ja avatud konteinereid) ja nende seisukorda (isegi ligunenud või rüüstatud kujul), geopeitjate kokkutulekuid (st sündmusaaretel toimuvat), üldvaateid peidiku piirkonnast.

Pildilise representatsiooni loomise mõttes on huvitavad aarded, mille puhul foto logisissekandes on lausa nõutud, selleks et aare loetaks leituks. Nüüdisaegse pildistamislembuse ning selfide ajastul pole see ka midagi erilist, kohustusliku fotoga aarded mitmekesistavad mängu lihtsalt veel ühe aspekti poolest. Tõsi, mõned mängijad eriti ei poolda niisuguseid aardeid, mille puhul eeldatakse otsija astumist aparaadi objektiivi ette. Nimetatud seik tuli kõneks, kui küsisin geopeituse foorumis luba kasutada logides leiduvaid fotosid Akadeemilise Rahvaluule Seltsi 2012. aasta kogumiskonverentsi ettekandes näitamiseks. ${ }^{8}$ Oma osavõtt või sooritus peab olema pildil näiteks veebikaamera aarete puhul (aardeks ongi kaamerapildil geopeitjad, mõnikord teatud lisaülesannet täitmas), Rakvere teatri ees tuleks poseerida koos "Kaduviku meestega" (vt Kaduviku mehed 2007) ja Kaali kraatrite juures Kaali järve taustal, GPS aparaat käes (sealne Earth cache tüüpi aare tähendab kohta, kus on toimunud planeedi ajaloos märkimisväärne muutus, vt Kaali kraatrid 2007). Teistel juhtudel kinnitab otsingu lõpliku tulemuse aarde tutvustuses leiduva tingimuse täitmine, näiteks Tartu botaanikaaeda peidetud aare on leitud, kui logis leidub foto ühest botaanikaaias

${ }^{8}$ Vt Kalda 2012. 
kasvavast taimest koos eesti- ja ladinakeelse nimega, foto aga peab olema tehtud aardeotsija enda poolt kindlasti TÜ botaanikaaias (vt Hortus Botanicus 2008). Leidlikku pildistamismängu kujutab endast Tramm kosmoses - aardeks on objekti sattumine teatud kohta teatud ajahetkel ning selle juhtumi jäädvustamine. Aprillikuu seisuga 2018 on haruldane konstellatsioon tabatud 84 korral: antud koordinaatidel Tallinnas on pildistatud Tondi suunas liikuv tramm numbriga 98, kusjuures pildil on näha ka kino Kosmos. Peitja Jazzy sõnul peab olema väga kannatlik, sest õige vaguninumbriga trammi peab väga kaua ootama (vt Tramm kosmoses 2007).

Tehtud fotod moodustavad omamoodi aegrea muutuvate ja muutumatute detailidega. Kaduviku meeste ümber seisvad inimesed - lapsed, naised ja mehed vahetuvad, samuti teatrietenduste plakatid skulptuuri taga teatri seinal; botaanikaaias vahetuvad aastaajad, samuti kaamerasilma läbi tähele pandud puud-põõsad ja lilled, ka on läbitud taimetundmise minikoolitus; kaadrisse on tabatud erilise numbriga tramm ja nurgake Eesti pealinnast öösel ja päeval, vihmasajus ja päikeses. Geopeitjad on oma rännakutel jäädvustanud Kiipsaare majaka merrejäämise ning viltusest asendist vertikaalseks kerkimise protsessi ajas (vt Kiipsaare 2004). Kui kusagil on vaja niisuguse muutuse pildilist kajastust, siis nimetatud paika külastanud geopeitjad on selle järk-järgult loonud veidi rohkem kui 100 külastuskorra käigus aastatel 2004-2018. Kui geopeituse andmekogu koondub osalejate ühise panustamise teel, siis põhimõtteliselt laieneks ühise andmekasutuse ring veelgi, kui geopeitjate poolt tehtud fotosid laetaks alla ja need leiaks kasutamist geopeitusest väljaspool. Loomulikult eeldab küll avalikult juurdepääsetava, ent eriotstarbelise andmekogu kasutamine eelnevaid kokkuleppeid. Suur hulk geopeituse fotosid liigituvad põhimõtteliselt etnograafilise foto kategooriasse - eristavaks on asjaolu, et nende tegemise eesmärk pole olnud etnograafiline jäädvustamine, vaid harrastusega seotud olude ja enda soorituse illustreerimine. Kui põhimõtteks on, et mitte iga uurimisväljal pildistatud foto pole etnograafiline foto, siis ei kvalifitseeru geopeitjate poolt üles võetud detailid ja asetused etnograafiliseks fotoks. Kui aga lähtuda pildil kujutatud olenditest ja seisunditest ehk vaadata pildi sisu, pole põhjust seda eitada.

Traditsiooni kogumise küsimuseks oli, kas geopeituse representatsiooni peaks jäädvustama veel muul moel, kui seda teeb harrastajaskond ise oma tegevuse koduleheküljel Internetis ja kas 


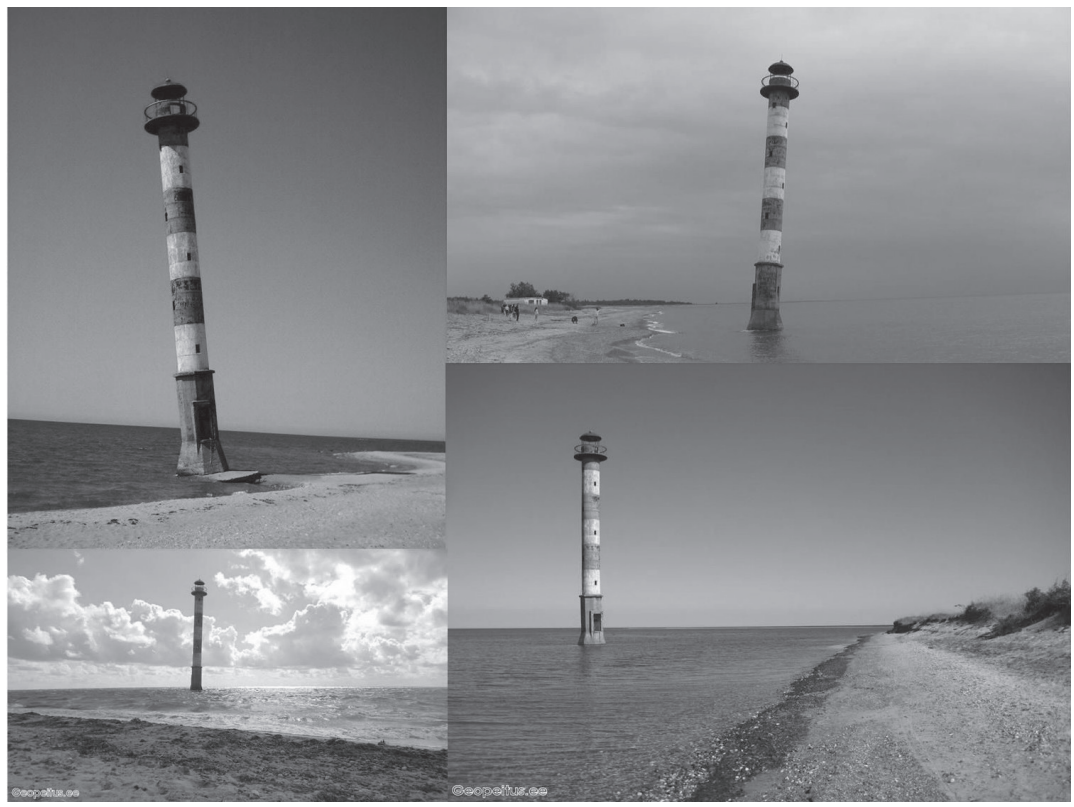

Kiipsaare tuletorn geopeituse fotodel 2004-2017. Kollaaž nelja valitud pildiga logiteadetes (vt Kiipsaare 2004).

sealjuures koguda ka fotosid. Tagavarasalvestamise korral tulevad aardelehekülgedel leiduvad fotod muidugi teiste andmetega kaasa. Tehniliselt on võimalik fotosid eraldi alla laadida ja isegi kasutada, kui tegevus järgib autoriõiguse seadust ja muid häid tavasid. Üheks geopeituse-väliseks kohaks, kus näidata geopeituse fotosid, on ilmselt uurimisartikkel, kui väljaande formaat illustratsioone võimaldab. Geopeitust kajastavad visuaalselt ka meediaväljaanded kas harrastuse tutvustuseks või kui tegevus pääseb uudisekünnisele mõne ebameeldiva vahejuhtumi, näiteks pommipaanika tõttu (vrd Teder \& Aasma \& Kõrvits 2017; samas on klikitav video aaret puistavast robotist). Tavaliselt ajakirjanik ei kogu geopeitus. ee sisu, vaid pildistab ise või teeb video ajakirjandusliku eksperiment-otsingu käigus ja uudise jaoks. Nii aardeid ette valmistades, peites kui otsides tegelevad harrastajad omapoolse kogumistööga: kogutakse informatsiooni ja kohti, ühtlasi ka elamusi. Kohtade (ja 
elamuste) kogumine toimub kehaliselt, kohale minnes ja kohal olles, kusjuures igaühe kollektsioon on näha registreeritud kasutajatele kättesaadaval individuaalsel aarete kaardil harrastuse kodulehel: seni leidmata aaret tähistav täpp kaardil värvub resultatiivse otsimise järel roheliseks - nii-öelda kohtadekogusse lisandub uus tähis. Elamusi ei saa tähistada täpikesega kaardil, kuid koguda saab täpikesi kaardil. On visuaalselt kiiresti haaratav, kuidas algselt leidmata aarete tunnustäpp asendub leitud aarete tunnustäpiga. Ent ka elamused on geopeituse andmekogus olemas - sisse pildistatuna geopeituse loodusfotodesse (päikesetõusud ja -loojangud, floora ja fauna, ilmaolud), paradokse ning kimbatust kujutavatesse piltidesse (raskel maastikul kinni jäänud auto, märjad riided, sääseparv otsijate kallal, ületamatu (vee)takistus teekonnal, kõrgele ronimise väljakutse, näiliselt avanematu aardekonteiner jne), aga ka otseselt emotsioonifotodesse (siiras vaimustus, kordamineku rõõm, saladusse pühendatu kaval näoilme jne). Need näidete read õhutavad omakorda kollektsionääri kirge: tahtmist niisugust vahetut kajastust jäädvustada.

Kohti mängu otstarbel uuesti asustades ning kajastades paigutub geopeitus seniste nii ametkondlike kui individuaalsete kohtadest huvitujate hulka. Niisiis tegutseb pärast 2001. aastat geopeitjate näol veel üks maastikuinspekteerijate grupp lisaks geodeetidele, muinsus-, keskkonna- ja looduskaitsjatele, matkajatele ja orienteerujatele, pärandkultuuri kaardistajatele ning kohapärimuse kogujatele jt. Kõik valdkonnad teevad välitöid, kirjeldavad ja pildistavad käidud kohti. Seega on kohad iga kandi pealt ära kaardistatud, kogu aeg toodetakse juurde kohtade pildilist representatsiooni. Igal huvirühmal on oma andmepank ja fotokogu. Muul moel see ilmselt ei toimikski - küllap oleks kummaline oodata, et arheoloogiaregister sisaldaks geopeitus.ee-st kogutud fotosid. Matkaja vajab käidud paikade kohatunde kinnistamiseks enda tehtud fotot ega laena seda Eesti Looduse Infosüsteemist (EELISest). Geopeituse võrgukeskkond võib sisaldada muudest fotopankadest (ja raamatutest, meediast jm) pärit pilte. Sel juhul kuuluvad need aarde peitmise informatsiooni hulka või kui nad leiduvadki logisissekannetes, siis funktsioneerivad viidetena, et illustreerida mõnd eriaspekti. Logiteadete fotod teevad mängijad ise otsimiste-peitmiste käigus ning suvel 2018 sisaldas geopeitus.ee juba 60010 pilti $^{9}$.

${ }^{9}$ 2012. aasta oktoobris, mil tutvustasin Eesti Rahvaluule Seltsi konverentsil geopeituse pildiloomet ja -kasutust, oli fotosid 22832 (andmed artikli autori valduses). 


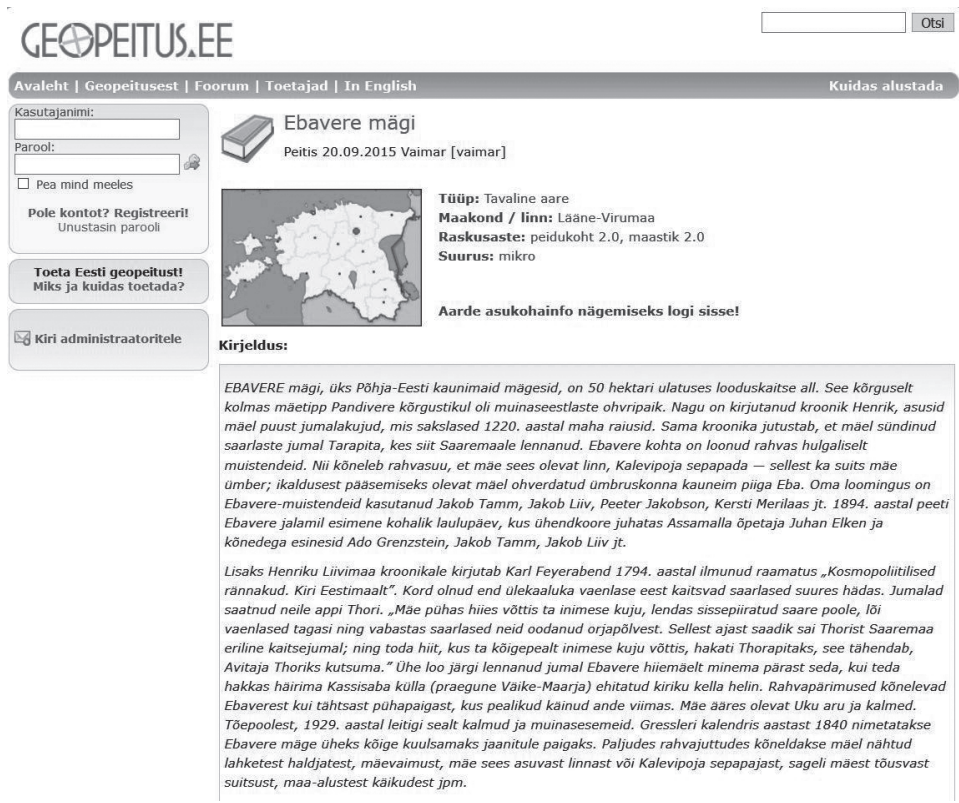

Geopeituse aare Ebavere mäel - näide geopeituse ja kohamuistendite kohtumisest. Legendid kuuluvad aarde kirjeldusse (Ebavere mägi 2015).

Kohamuistendeid uurides ning nende maastikulisi seoseid otsides olen avastanud lehel geopeitus.ee väga häid võtteid legendidega seotud kohtadest. Muistendikohtadesse aaretepeitmine on iseenesest huvitav maastiku hõlvamise viis (seda on muidugi geopeitus tervenisti), geopeitus on muistendeid uuesti aktualiseerinud ja tekitanud suunatud külastuste voo. Sellise praktika käigus pöördutakse uuesti ka muistendi teksti poole, jutt tuleb otsekui uuesti käibele. Folkloori ja folkloristika perspektiivist vaadates on tegu tähelepanu vääriva suunaga harrastuses. Kui ka geopeituse mängu-iseloomust veel ei piisa põhjendamaks harrastuse kogu representatsiooni varundamist, siis muistendite kasutamine geopeituse huvides on küll alateema, mille kulgu pärimuse uurija peaks koguma, registreerima ja kirjeldama.

Olen ühes varasemas käsitluses (Kalda 2007, 107-110) põgusalt viidanud ka geopeituse logides üles astuvale aardevalvurile, kes traditsioonilistes muistendites oli valdavalt mütoloogiline tegelane 
ning täitis muistendi sisus kindlat rolli (temast sõltus, kas inimtegelane pääses või ei pääsenud varanduse juurde). Niisiis mitte ainult muistendi tegevuskoht (kui aare on peidetud kohajuttudega seotud paika), vaid oluline aardemuistendite tegelane on integreeritud geopeitusega. Aardevalvuri kuju on geopeitusemängus rakendatud tegelikult sõltumatult sellest, kas geopeidik on seatud muistendiga seotud paika või mitte. Niisiis realiseerub siin idee - mille taustaks on uskumus, - et aardel on valvur, nagu ennemuistsetel varandustel nii ka mänguotstarbelistel aaretel. Aardevalvuri kujutis võimaldab tõlgendada geopeitusega muidu mitte seotud olendeid ja esemeid siiski mänguliselt geopeitusesse kuuluvana. Niisuguseid "aardevalvureid" on sageli pildistatud. Kunagise mütoloogilise olendi mängulisse, naljatavasse uude konteksti asetamise näidetena väärivad geopeituses kehastatud aardevahid kindlasti talletamist.

Geopeitust harrastades satub osaleja looduslikesse pühapaikadesse ja kohamuistendite tegevuskohtadesse (nt Kiigeoru hiiesalu Tartumaal (vt Kiigeoru 2007), Kivilõppe Vanapagana kivi Viljandimaal (vt Vanapagana kivi 2007), Ebavere mägi Lääne-Virus (vt Ebavere mägi 2015), Savalduma puudeks muutunud pulmalised (vt Savalduma pulmajalakad 2014), Turje kelder (vt Vanapagana baarikapi 2002; Kalda 2007, 99-102) jne). Juba on näiteid sellest, et geopeitus vahendab uut kohapärimust, isegi sellist, mis mujal ei tarvitse veel dokumenteeritud olla. Mõnel juhul on tegu väljamõeldud looga, kuid teisal on aarde leheküljele kirjutatud suhteliselt hiljuti kohapealses või mingil muul moel organiseerunud kogukonnas levinud jutt. Näiteks Verijärvega ja selle lugudega seotud Plehkupannud krokodilli aarde tutvustusse kuulub koguni kaks muistendit: traditsiooniline kättemaksulegend Uue-Kasaritsa kurja härra uputamisest (avaldatud Rõuge kihelkond 2001, 83-85; leitav ka muudes kogumikes) koos "ühe uuema rahvajutuga".

Geopeitja Viper tutvustab oma aaret:

Uuem rahvajutt pärineb läinud sajandi viimastest kümnenditest ja räägib sellest, et ühel Võru mehel olnud koduloomaks väike krokodill. Mees käinud oma lemmiklooma aeg-ajalt Verijärves ujutamas. Ühel korral pääsenud aga krokodill nööri otsast minema ja pagenud järve. Rahvas räägib, et ta elutseb praeguseni järves ja käib ettevaatamatuid suplejaid vahetevahel varbast näksimas :) (vt Plehkupannud krokodilli 2008)

Aare peideti Verijärve äärde 2008. aasta kevadel ning selle senisesse kümneaastasesse ajalukku jääb 170 edukat ja 30 edutut külastust. 


\section{Geopeitus.ee kui väärtuslik võrguressurss}

Kui geopeitus.ee oleks tunnistatud kultuuripärandiks või rahvuskultuuri ning ühiskonna seisukohalt oluliseks võrguressursiks, kuuluks harrastusse kaasatud inimeste tegevuse kajastus tsentraalsele arhiveerimisele. Teadupärast on internetilehtedel leiduva kultuuripärandi või aja jooksul sellesse seisusesse saava informatsiooni säilitamiseks Eestis välja töötatud eriline strateegia. Andmeid laetakse pikaajaliseks hoidmiseks digitaalsesse "Eesti veebiarhiivi" (http:// www.nlib.ee/veebiarhiiv). Digitaalsesse hoidlasse lähevad valitud veebisaidid ning erikogud, mille moodustavad sündmuse- või teemapõhise arhiveerimise teel lisanduvad veebisaidid (vt Valikupõhimõtted 2015). Missugused "rahvuskultuuri ning ühiskonna seisukohalt eriti olulised" võrguressursid valikusse kuuluvad, sedastab mäluasutuste veebiarhiveerimise ekspertide koostatud loetelu. Sellesse kuulub nii asutuste kui ka eraisikute veebisaite, haridusasutuste infokeskkondi, meediaväljaannete lehekülgi, uudisteportaale, blogisid, foorumeid ja fotosaite põhimõttel, et seal leiduv sisu on oluline Eesti ühiskonna toimimise ja uurimise seisukohalt, sealhulgas ka kohalikku eripära ning kultuurinähtusi väljendav püsiva kultuuriloolise ja teadusväärtusega teave (samas). Ent Eesti veebiarhiivi meede siiski geopeituse jt taoliste keskkondade varundamisega ei tegele, kuna senise strateegia järgi ei arhiveerita registreerimist ja salasõna nõudvaid ja interaktiivseid veebilehti (kasutajapäringute ja foorumiga), üldpõhimõttena jäävad riiklikust veebiarhiveerimise aktsioonist kõrvale ka mängu-, meelelahutus- ja suhtlusportaalid (samas). Geopeituse veebileht aga eeldab täisvereliseks kaasategemiseks ning kõigile andmetele juurdepääsuks kasutajaks registreerimist (sisselogimine käib salasõnaga), leht on funktsionaalsuselt interaktiivne - kasutajad teevad sinna regulaarselt sissekandeid, samuti on võimalik muuta oma varasemaid postitusi. Väljastpoolt vaadates on kerge pidada saiti geopeitus.ee mänguportaaliks ning pelgalt meelelahutuseks. On ilmne, et seesolija leiab teema iseloomustamiseks rohkem kirjelduskategooriaid kui üksnes 'mäng' ja 'meelelahutus' (vt Kalda 2013, 236-246).

Kuigi geopeituseharrastus ei kvalifitseeru kohale Eesti veebiarhiivis, ilmneb huvitav paralleel Rahvusraamatukogu poolt esile toodud arhiveerimiskriteeriumide ning võimalike kogumispõhimõtete vahel, miks geopeituse representatsioon harrastuse koduleheküljel 
vääriks põhjalikumat jäädvustamist. Enamik parameetreid iseloomustavad ka geopeitust - erilist infotehnoloogilise kommunikatsiooniajastu harrastust, mis ühendab kaasahaaratud inimeste offline ja online tegevused ning realiseerib osalusveebi võimalusi mänguliseks infotöötluseks. Niisiis, võrgusisu on väärt jäädvustamist, kui see:

- on piisavalt oluline ja unikaalne, samuti kajastab eesti rahvuskultuuri ja eesti ajaloo seisukohalt olulisi sündmusi;

Geopeitusemänguga loodav andmestik tegelikult on rahvuskultuuri seisukohalt oluline, kuna jäädvustab Eestit võrdlemisi laias ulatuses. Aardelehekülgedelt leiame ühe koha kirjeldusi erinevatel ajahetkedel koos fotodega (näiteks Kiipsaare majakas Saaremaal, mis "peitmise"10 ajal augustis 2004 oli veel kuival maal, 2005 mere poole kaldu, 2009 aga juba täielikult meres, peaaegu vertikaalne) ja saame teada, missuguseid muljeid paigad külastajates tekitavad. Geopeitus kui mäng iseenesest ei liigitu küll "ajaloo seisukohalt oluliseks sündmuseks", ent traditsiooni kujundava tegevusžanrina vääriks see igal juhul märkimist.

- kui sellel leiduv teave omab uurimispotentsiaali;

Hindan geopeitus.ee uurimispotentsiaali lausa erakordselt kõrgeks: esiteks mängu enda toimumise raportina ning teiseks paljude uurimisküsimuste poolest, mida geopeituse andmete põhjal saaks selgitada (nii looduse kui linnaolude kirjeldused, harrastusega seotud kogemused ja kogemusest jutustamine, mängu ja mängu ümbritseva maailma seosed jne). Uurimispotentsiaali rõhutab ka tõsiasi, et kõik mängukorrad on kajastatud: toimimisaeg ja peitjate ning otsijate (kasutaja)nimed on fikseeritud. Arhiveerimiskriteeriumi sõnastus: "Veebisaidil sisalduv teave pakub olevikus ja tulevikus uurijale adekvaatset pilti konkreetsest nähtusest ja selle erinevatest avaldumisvormidest" (vt Valikupõhimõtted 2015) tabab geopeitus.ee puhul aga otse naelapea pihta.

\footnotetext{
10 Jutumärgid on kasutuses seetõttu, et Kiipsaare on nn virtuaalne aare, mille puhul laegast esemetega pole ning aardeleid tähendab paiga külastust koos teatud ülesannete täitmisega (määrata koordinaadid ja pildistada; vt Kiipsaare 2004). Uuemas geopeituses virtuaalseid aardeid juurde ei moodustata (rahvusvahelises mängus 2005. aastast hiljem koostatud aarete hulgas virtuaalseid peidikuid ei leidu).
} 
- kui sinna on andmeid kogutud pikaajaliselt;

Tegu on ilminguga, mida selle formeerumise algusest peale on internetilehel kajastatud, kajastus on ka kronoloogiliselt korrastatud (Eesti oludes alates 2001. aasta veebruarist, vt HE-aare 2001 ja Veenpere 2002).

- kui veebisait on identifitseeritav (saidil on tuvastatav autor või omanik);

Veebisait geopeitus.ee sisu koguneb geopeitjate kogukonna ühistegevuse käigus; lehekülge haldab alates 2016. aasta aprillist tegutsev MTÜ (kolmeliikmelise juhatusega), valitud mängijaile on antud moderaatori roll ja ülesanded;

- kui andmed on usaldusväärsed, s.t täpsed ja täielikud;

Andmed geopeituse veebis on usaldusväärsed ja täpsed harrastuse seisukohast, ent annavad mitmesugust sama usaldusväärset taustainformatsiooni ajaloo, asustuse, arhitektuuri, geograafia, ilmaolude jms kohta. Andmete täielikkus on, nagu ka eespool rõhutasin, niisuguse mängu mängureeglitest tulenev eripära, informatsiooni mitmekesisus ja kvaliteet on vältimatud mängu käigushoidmiseks. Erijooneks on asjaolu, et saidil leiduvad andmed on osalejate ühiskasutuses: ühtede mängijate poolt koostatud ja üles laetud sisu vajavad teised mängijad. Samas on geopeitjad huvitatud tagasisidest, kuidas kaaslased seda sisu kasutavad, kuidas ajendab informatsioon edasist dialoogi ja diskussiooni osalejate hulgas.

- kui veebisait on terviklik;

Geopeitus.ee on terviklik.

- kui tegu on väljaandega, mille sisu ja ülesehitus võimaldab kergemini leida vastavat teavet või teavet süstematiseerida.

Geopeitus.ee sisu ja ülesehitus on kujundatud selliselt, et kasutaja leiaks talle vajalikku teavet. Ka juhuslik lehel surfaja saab muidugi ülevaate, millega on tegu. Tõsi küll, harrastuse kodulehekülg sisaldab rohkem interaktiivseid sünkroonseid võimalusi, mida kaasategijad vajavad ja kasutavad, ent mille funktsionaalsus ei säili arhiveerituna.

Geopeituse vaatlus Rahvusraamatukogu veebiarhiveerimise toimkonna poolt sõnastatud veebiarhiveerimise kriteeriumide põhjal kaldub toetama vajadust geopeitus.ee sisu periooditi alla laadida. Siis oleks see Internetis võib-olla aset leidvate juhuslike või tahtlike 
muutuste korral olemas. Kultuuri suurandmete koondamise kavatsustesse geopeituse andmekogu tagavarakoopia loomine praeguse seisuga ei kuulu. Tõsi, saidil leiduvat sisu ei paista ähvardavat kadumisoht: Eesti mängu 17aastase ajaloo jooksul geopeitjate poolt postitatud 45000 logi ja muud teadet, 60000 pilti ja 26000 foorumipostitust (kõik statistilised andmed on pärit geopeitus.ee statistika alamleheküljelt http://www.geopeitus.ee/statistika) sisalduvad korralikult struktureeritud andmebaasis, kuhu tulevad juurde uute otsimiskordade logid ja uute aarete kirjeldused. Andmekogu on varustatud vajalike päringuvõimalustega, selles navigeerimine, samuti kaartide ja GPSi kasutamine on tehtud hõlpsaks ja võimalusterohkeks.

Senises käsitluses esile tõstetud aspektid näitasid, miks on geopeitus traditsiooni kogumise ja uurimise seisukohalt huvitav, kõnekas ja väärtuslik. Pärast etnograafilise andmekogumise tavade kõrvutamist uuritava traditsiooni kajastuse loomisega selles traditsioonis osalejate endi poolt interaktiivses veebis, arvan jätkuvalt, et andmekogu annab täieliku ülevaate mängus toimuvast. Lehekülg geopeitus.ee ei kujuta endast muidugi rahvaluulesaiti, geopeituse ja folkloori vahele ei saa panna võrdusmärki. Geopeitusel kui mängul on siiski koht folkloori žanrisüsteemis. Uurides geopeitust, saame informeerituks ühest mängimise viisist 21. sajandil, seega võimaldab geopeitus jälgida arengut mängude žanris. Folkloristlik perspektiiv võimaldab tähele panna ka seoseid teiste tegevusfolkloori liikidega tähistamiste ja rituaalidega, kuna needki mahuvad igapäevasesse geopeitusesse. Väga hästi on näha osalejaskonna kujunemine ja suhtlus, peamiselt internetikogukonnana, kuid kokkupuuteid on ka tavareaalsuses. Suhtluse saadusteks on postitused geopeituse saidil - põhimõtteliselt on tegu pärimusrühma sisese suhtlusega, mis hõlmab ühendava tegevuse ja teemade kohaseid jutustusi, nalju, tähtpäevi, terminoloogiat, tegemisviise. Seega folkloristi pilgule avaneb mängu representatsioon, mida pole olnud vaja eraldi küsida ega arhiveerida, ent uuritava nähtuse kõik ilmnemiskorrad, nii-öelda variandid on sellest hoolimata juba dokumenteeritud. Folkloristidega võrreldes teisele huvigrupile kuuluvate andmete uurimise ja jälgimise legitimeerib minu hinnangul vastastikune teadlikkus ja koostöövalmidus: geopeitjad (pärimusrühm) on teadlikud, et nende saidil toimuva vastu tunnevad huvi kultuuriuurijad (teaduskollektiiv). Uurimine kujutab endast pärimuskollektiivi ja teaduskollektiivi ühistegevust (vrd Honko 1998, 76). Väide on 
seda kõnekam, et aktiivsed geopeitjad ju ise ka reflekteerivad oma tegevust, näiteks foorumis. Kui folkloristilt teadlasena oodatakse pärimusainesest uue teadmise loomist (mida "muud pärimusainesest huvitujad ega pärimuse harrastajad ise ei loo", vt Honko 1998, 77), siis geopeituse vaatlejale on kogu geopeituse andmekogu teatud mõttes uus teadmine. Geopeitjad pärimusrühmana ise loovad uut teadmist, struktureerivad olemasolevat informatsiooni ümber ning täiendavad seda oma harrastuse spetsiifikaga. Folklorist kui teadlane saab "uut teadmist toota" ainult seeläbi, et tema uuritav kogukond on oma tegevust harrastades ja representeerides loonud eripärast uut teadmist. Folklorist lisab siia omalt poolt traditsioonianalüütilise teguri - selle, mis mõttes ja kuidas on uuritav nähtus traditsiooni loov ja traditsiooni kuuluv.

Tänapäevases teabe levimise ja kasutamise ning informatsioonitehnoloogilise suhtluse tingimustes osutub geopeitus.ee huvitavaks allikaks, kust leiab nii sõnas kui pildis andmeid nii harrastuse enda kui ka selle maailma kohta, kus harrastus teoks saab. Geopeitus on väärt folkloristlikku kaasategevat uurimist. Seni, kuni geopeituse andmeid ei salvestata täielikult säilitamisele kuuluvate kultuuri võrguressursside hulgas, on mõistlik teha uurimisotstarbelisi väljavõtteid ja regulaarselt jälgida uudiseid keskkonnas www.geopeitus.ee, kuid olla kursis ka suure geopeituse kajastusega leheküljel www.geocaching.com.

Artikkel on valminud uurimisteema IUT 22-5 "Folkloori narratiivsed ja usundilised aspektid" raames ja seda toetas Euroopa Liit Euroopa Regionaalarengu Fondi kaudu (Eesti-uuringute Tippkeskus).

\section{Kirjandus}

Aarseth, Espen 2003. Playing research: Methodological approaches to game analysis. Paper presented at the 5th Digital Arts \& Culture Conference, Melbourne, Australia (http://www.bendevane.com/ VTA2012/wp-content/uploads/2012/01/02.GameApproaches2.pdf 23.10.2018).

Abrahams, Roger 1977. Toward an Enactment-Centered Theory of Folklore. - Bascom, William (toim). Frontiers of Folklore. Boulder: Westview Press, 79-120.

Arukask, Madis 2017. Folkloori talletamine ja talletajad. Välitööd internetis. - Metsvahi, Merili (koost). Folkloristlikud välitööd. Tartu: Tartu Ülikooli kirjastus, 12-23.

AutÕS = Autoriõiguse seadus 1992. - Riigi Teataja I, 49, 615 (https://www. riigiteataja.ee/akt/114062013005 - 23.10.2018). 
Honko, Lauri 1998 [1990]. Folklooriprotsess. - Mäetagused 6, 56-84 (doi: 10.7592/MT1998.06.honko).

Hurt, Jakob 1963 [1871]. Mis lugu rahva mälestustest pidada. - Laugaste, Eduard (koost). Eesti rahvaluuleteaduse ajalugu [1]. Valitud tekste ja pilte. Tallinn: Eesti Riiklik Kirjastus, 192-200.

Hurt, Jakob 1963 [1888]. Paar palvid Eesti ärksamaile poegadele ja tütardele. - Laugaste, Eduard (koost). Eesti rahvaluuleteaduse ajalugu [1]. Valitud tekste ja pilte. Tallinn: Eesti Riiklik Kirjastus, 202-210.

Ihamäki, Pirita 2015. Social tribe culture case study: Geocaching game. - International Journal of Web Based Communities 11 (1), 97-113 (doi: 10.1504/IJWBC.2015.067087).

Kalda, Mare 2007. Muistendid uues kontekstis - geopeituses. - Kõiva, Mare (koost). Paar sammukest XXIII. Eesti Kirjandusmuuseumi aastaraamat. Tartu: Eesti Kirjandusmuuseumi teaduskirjastus, 93-116 (http://www.folklore.ee/rl/pubte/ee/araamat/2007/4marekalda.pdf 24.10.2018)

Kalda, Mare 2012. Kakskümmend kaks tuhat kogumata pilti. Ühe hobi enesekajastusest. - Pildi sisse minek. Akadeemilise Rahvaluule Seltsi kogumiskonverents Tartus, 24. oktoobril 2012. Tartu: EKM Teaduskirjastus, 7 .

Kalda, Mare 2013. Geopeitus - 21. sajandi harrastus mängu žanriraamis ja väljaspool. - Kõiva, Mare (koost ja toim). Maailm ja multitasking. Tänapäeva folkloorist 10. Tartu: EKM Teaduskirjastus, 221-254 (doi: 10.7592/TF10.geo).

Kapchan, Deborah A. 2003. Performance. - Feintuch, Burt (toim). Eight Words for the Study of Expressive Culture. Urbana: University of Illinois Press, 121-145.

Kaplan, Merrill 2013. Curation and Tradition on Web 2.0. - Blank, Trevor J. \& Howard, Robert G. (toim). Tradition in the Twenty-First Century. Locating the Role of the Past in the Present. Logan: Utah State University Press, 123-148 (doi: 10.7330/9780874218992.c05).

Montola, Markus 2012. Social Constructionism and Ludology: Implications for the Study of Games. - Simulation \& Gaming 43 (3), 300-320 (doi: 10.1177/1046878111422111).

Neustaedter, Carman \& Tang, Anthony \& Judge, Tejinder 2010. The Role of Community and Groupware in Geocache Creation and Maintenance. - Proceedings of the SIGCHI Conference on Human Factors in Computing Systems, 10-15 April 2010, Atlanta, Georgia. New York, 1757-1766 (doi: 10.1145/1753326.1753590).

O'Hara, Kenton 2008. Understanding Geocaching Practices and Motivations. - Proceedings of the 26th Annual SIGCHI Conference on Human Factors in Computing Systems, April 5-10, 2008, Florence, Italy, 1177-1186 (doi: 10.1145/1357054.1357239). 
Oring, Elliott 2013. Thinking through tradition. - Blank, Trevor J. \& Howard, Robert Glenn (toim). Tradition in the Twenty-First Century. Locating the Role of the Past in the Present. Logan: Utah State University Press, 22-48 (doi: 10.7330/9780874218992.c01).

Pilt, Maili 2017. Välitööd internetis. - Metsvahi, Merili (koost). Folkloristlikud välitööd. Tartu: Tartu Ülikooli kirjastus, 160-179.

Puik, Vahur 2008. Veebist, ülepildistamisest, muuseumiaastast ja rahvast ehk teeme ometi talgud ja jätame jalgratta leiutamata. - Muuseum. Eesti Muuseumiühingu ajakiri 2 (24), 5-8 (https://www.muuseum.ee/ wp-content/uploads/2017/11/muuseum_24_2_2008.pdf-25.10.2018).

Putnam, Robert D. 2000. Bowling Alone: The Collapse and Revival of American Community. New York: Simon \& Schuster.

Rõugekihelkond=Remmel,Mari-Ann \& Potter,Terje \& Valk,Heiki(koost) 2001. Rõuge kihelkond. Paigadja pärimus. Tartu: Eesti Kirjandusmuuseum.

Saarlo, Liina 2017. Regilaul tuulte pöörises. Eesti folkloristid poliitiliste muutuste ajajärgul 20. sajandi keskel. - Methis. Studia humaniora Estonica 20, 27-54 (doi: 10.7592/METHIS.V16I20.13888).

Sarv, Mari 2017. Folklore collections in the service of Estonian society: Integrity in diversity. - Goršič, Ave \& Järv, Risto \& Sarv, Mari (toim). Archives as Knowledge Hubs: Initiatives and Influences. Estonian Literary Museum September 25-28, 2017, Tartu, Estonia, 54-55.

Sarv, Mari \& Särg, Taive 2016. Kelle jaoks on mõeldud eesti rahvaluulekogud: Jakob Hurda unenäod ja tegelikkus. Eesti Rahvusraamatukogu. -Eesti mäluasutuste suveseminar "Kultuuripärand - avastamata rikkus" 24.-25. augustil 2016 Viinistu kultuuri- ja konverentsikeskuses Kuusalu vallas Harjumaal. Võrgudokument (https://www.nlib.ee/ public/documents/tradits_yritused/Malu_seminarid/2016/Hurda_ unenaod_Sarv.pdf - 24.10.2018).

Tangherlini, Timothy 2013. The Folklore Macroscope: Challenges for a Computational Folkloristics. The 34th Archer Taylor Memorial Lecture. - Western Folklore 72 (1), 7-27 (http://tango.bol.ucla.edu/ publications/A99.pdf - 24.10.2018).

Teder, Teet \& Aasma, Kristin \& Kõrvits, Greete 2017. Pommipaanika Ekspress Grupi õuel põhjustas süütu, kuid mõtlematu mäng. - Ôhtuleht, 7.04 (https://www.ohtuleht.ee/798125/ohtulehevideo-pommipaanika-ekspress-grupi-ouel-pohjustas-suutu-kuidmotlematu-mang - 23.10.2018).

Valikupõhimõtted 2015 = Eesti veebiarhiivi valikupõhimõtted. - Eesti Rahvusraamatukogu (http://www.nlib.ee/index.php?id=21558 alates 2017. aasta lõpukuudest pole dokument enam avalikuks kasutuseks kättesaadav. Autori märkus).

Veenpere, Enn 2002. Aasta geopeitust Eestis. - Arvutimaailm 1, 41-43.

Västrik, Ergo-Hart 2017. Folkloori jäädvustusviiside muutumine. Välitööd internetis. - Metsvahi, Merili (koost). Folkloristlikud välitööd. Tartu: Tartu Ülikooli kirjastus, 29-48. 


\section{Viidatud aarded ja geopeituse alarubriigid (aastaarv märgib aardepeitmise aega või teemapüstituse algust, kõik allikad viimati vaadatud 15.10.2018)}

10 aastat geopeitust Eestis [foorumiteema] 2011. http://www.geopeitus.ee/ foorum/read.php?1,13973

Ebavere mägi 2015. http://www.geopeitus.ee/aare/3567

HE-aare 2001. http://www.geopeitus.ee/aare/1

Hortus Botanicus $2008=$ Hortus Botanicus Universistatis Tartuensis. http:// www.geopeitus.ee/aare/923

Kaali kraatrid 2007. http://www.geopeitus.ee/aare/647

Kaduviku mehed 2007. http://www.geopeitus.ee/aare/574

Kiigeoru 2007. http://www.geopeitus.ee/aare/578

Kiipsaare 2004. http://www.geopeitus.ee/aare/260

Lacrimae professorum 2009. http://www.geopeitus.ee/aare/1208

Mängureeglid [2018]. http://www.geopeitus.ee/wiki/reeglid

Naistepäeva 2012. http://www.geopeitus.ee/aare/1786

Naistepäeva 2 2013. http://www.geopeitus.ee/aare/2279

Plehkupannud krokodilli 2008. http://www.geopeitus.ee/aare/782

Savalduma pulmajalakad 2014. http://www.geopeitus.ee/aare/3233

Statistika. http://www.geopeitus.ee/statistika

Sõnastik; vt https://www.geopeitus.ee/wiki/sonastik

Tramm kosmoses 2007. http://www.geopeitus.ee/aare/690

Vanapagana baarikapi 2002. http://www.geopeitus.ee/aare/58

Vanapagana kivi 2007. http://www.geopeitus.ee/aare/604

\section{Summary}

\section{On Collecting of hobby group folklore: The case of 'Geopeitus' (Geocaching in Estonia)}

Keywords: collection of folklore, collaboration with tradition group, geocaching

The website www.geopeitus.ee provides an overview of the course of a special treasure-hunting game. The site contains a plethora of image- and wordbased content about the game played through digital technology, as well as the world were this practice is performed. Geocachers represent regularly the process of playing, but they also take ethnographic notes and take photos of and describe places linked to traditional folklore. They collect data 
about the surrounding world and post their observations on the website of the game they maintain.

In a sense, they operate collectively as a tradition group with a special practice while also acting as ethnologists or folklorists who describe their practice through autoethnography. As a result, the geocaching website makes up an interesting database that attracts experts to observe the game. Communication researchers, cultural geographers, psychologists, game analysts, IT developers and most certainly also ethnologists and folklorists have taken an interest in geocaching. The question of collecting material under new conditions alone presents an interesting challenge for a folklorist: how does one proceed when the tradition or enactment of interest has been aggregated not for the purpose of collection of folklore, but by the performers or enactors of the observed tradition? If the communities engaged in the tradition are recording the tradition in a shared environment of information and communication, if they reflect their activities online in a continuous and versatile manner - how can this substantial database be incorporated with the sources used by folklorists?

The general principles of folklore collection in Estonia were provided in the final decades of the 19th century. Tradition was valued as a book of time, and attention was awarded to its entertainment purpose as well as educational aspect. These properties have stood the test of time and can be observed in the collection and study of something as modern as geocaching. In the 21st century, folklore studies have focussed on observing largely synchronous phenomena. Another thing that makes the geocaching database so fascinating is the way in which the data generation and transfer in the present requires and reproduces information from the past, including traditional folklore.

Geocaching, which started in the state of Oregon in the U.S. on 3 May 2000 (see www.geocaching.com), known in Estonian as geopeitus (from February 2001, see www.geopeitus.ee) and other local versions, can be interpreted as a part or phenomena of noninstitutional culture. This hobby also establishes specific culture, forms tradition and the group of participants practising it. During the years geocaching has been active, the game has developed an international or even global way of practice with local peculiarities appearing in parallel as smaller geocaching communities play the game. This means that even a touch of tradition will cause folklorists to be interested in geocaching.

Research value comes down to a number of aspects: the nature of geocaching that illustrates the renewal of the game genre in the 21st century; the development and dynamics of players as a gaming community; the development of geocaching folklore; the birth of in-game customs and rituals; the specifics of terminology and language use as well as the manner of writing logs (i.e. notifying others of searches) and exchange of experience; 
events happening during the game and the viewpoint of the geocachers participating in the events; maintenance of the game and the website of the hobby, etc.

Another peculiarity of geocaching as a research source is the fact that an overview of the events taking place is already aggregated without ethnographic collecting (all variants of the phenomenon under study are already registered). This in itself does not ensure permission to use data by default and does not release the researcher of tradition of the need to conduct interviews and make (participatory) observations. It is effective to take the position of an engaging researcher as stressed in the study of location-based and computer games alike. The community under research should of course be informed of the fact that their hobby is the target of academic interest. Every research process includes collaboration between the ethnographer and the community under research, even if a description of the culture is attainable by examining online data and there is no particular need for conducting a survey.

The article concludes that even though "everything seems to be available online" and there is no immediate danger that data of interest might disappear, there is still reason to save a sufficient number of examples both for preservation and research purposes. 


\section{PILDI SISSE MINEK. Artikleid välitööde alalt}

\section{Koostanud ja toimetanud EDA KALMRE}

http://www.folklore.ee/rl/pubte/ee/cf/pildisisse

ISBN 978-9949-586-93-6

DOI $10.7592 / \mathrm{TF} 11$

Tartu 2019

Trükis ilmunud:

Pildi sisse minek. Artikleid välitööde alalt.

Tänapäeva folkloorist 11. Tartu 2019

Sarja peatoimetaja: Eda Kalmre

Kogumiku koostaja ja toimetaja: Eda Kalmre

Keeletoimetaja: Asta Niinemets

Kaanekujundus: Artur Kuus

Küljendus: Diana Kahre

Veebiväljaanne: Diana Kahre

Trükitud Eesti Kultuurkapitali toetusel. Väljaande valmimine on seotud Euroopa Liidu Euroopa Regionaalarengu Fondi (Eesti-uuringute Tippkeskus) ja Eesti Haridus- ja Teadusministeeriumi uurimisprojektiga IUT 22-5. Väljaande valmimist on toetanud Akadeemiline Rahvaluule Selts.

E-raamatu valmimist toetas: EKKM14-344 Eesti keele, kultuuri ja folkloori kasutusalade laiendamine ja tutvustamine elektroonilistel infokandjatel.

(C) Eesti Kirjandusmuuseum 2019

(C) Eda Kalmre ja autorid

(C) Artur Kuus 